\title{
STIGMASTEROL CONTENT OF ARTEMISIA ANNUA L. AND THE PHYTOSTEROL PROFILE
}

\author{
FADJAR AJU TOFIANA ${ }^{1 *}$, IMMACULATA IWO M $^{2}$, RAHMANA EMRAN KARTASASMITA ${ }^{2}$, ELFAHMI ${ }^{3}$
}

${ }^{1}$ Deputy of Traditional Medicines, Cosmetics and Complementary Product Control, National Agency of Drug and Food Control, Republic of Indonesia. ${ }^{2,3}$ School of Pharmacy, Institut Teknologi Bandung, Indonesia, ${ }^{4}$ Bioscience and

Biotechnology Research Center, Institut Teknologi Bandung, Indonesia. Email: tofiana@gmail.com

Received: 24 June 2016, Revised and Accepted: 25 July 2016

\section{ABSTRACT}

Objective: To find the stigmasterol source of Artemisia annua L. and to study the profile of phytosterol types in A. annua hairy root cultures.

Methods: Stigmasterol content determination was done based on stigmasterol content in the methylene chloride extract of $A$. annua using high performance liquid chromatography in wild-type plant, plant tissue cultures, and hairy root cultures. The optimal resolution was achieved by suitability system, and stigmasterol calibration curve was generated with stigmasterol concentrations series. Phytosterol types in $A$. annua hairy root cultures were performed by gas chromatography-mass spectrophotometry.

Results: Highest stigmasterol content in $A$. annua is shown by hairy root cultures of $A$. annua in the $5^{\text {th }}$ week harvesting time, which is $1.5 \mathrm{~g} / 100 \mathrm{~g}$ (w/w) extract. The phytosterol profile in $A$. annua hairy root cultures encompassed stigmasterol $74.6 \%$, $\beta$-sitosterol $13.5 \%$, and campesterol $11.9 \%$.

Conclusion: A. annua hairy root cultures in 5-week harvesting time prove its potential as stigmasterol source alternative. The highest phytosterol type in A. annua hairy root cultures is stigmasterol. This is the first report stigmasterol content and its phytosterol profile of $A$. annua hairy root cultures extract.

Keywords: Artemisia annua L., Wild-type plant, Plant tissue cultures, Hairy root cultures, Stigmasterol.

\section{INTRODUCTION}

Stigmasterol, one of phytosterol components in plant, is the $3^{\text {rd }}$ biggest constituent following $\beta$-sitosterol, and campesterol $(3 \%, 65 \%$, and $30 \%$ respectively) [1]. Although stigmasterol has a low concentration, the benefit of stigmasterol is wide in our lives. Roles of stigmasterol have been approved such as anti-osteoarthritic by blocking cartilage degradation in a rabbit model of osteoarthritis [2,3] and anti-cholesterol by lowering blood cholesterol level [4-7]. Stigmasterol could also be used as food additives, as a stabilizer in ready-to-freeze alcoholic cocktails [8]. The highest stigmasterol content is in corn oil (61.28$61.30 \mathrm{mg} / 100 \mathrm{~g}$ edible portion) [9]. Artemisia annua transformed by Agrobacterium rhizogenes ri strain 1601 produces stigmasterol [10], and the stigmasterol content was estimated to be 201 times greater than artemisinin content [11]. An observation was made by comparing between $A$. annua, from the wild-type plant, plant tissue cultures and its hairy root cultures which have no previous report. An alternative of stigmasterol source will bring benefit both in economical and environmental factors. Moreover, it uses A. annua hairy root cultures which have been transformed by A. rhizogenes ri strain 07-20001 [12].

\section{METHODS}

\section{Materials}

All chemicals and solvents were of analytical grade. Thin layer chromatography (TLC) plates were aluminum precoated with silica gel $\mathrm{GF}_{254}$ (Merck, Germany). Stigmasterol (Sigma, Switzerland). High petroleum liquid chromatography (HPLC) analysis was performed using Shimadzu A 200, C18 Column (X-Bridge): $250 \mathrm{~mm} \times 4.6 \mathrm{~mm}$. Gas chromatography-mass spectrometry (GC-MS) analysis was performed using Varian 320MS, Rtx-5MS column and helium gas as mobile phase. A. annua wild-type plant was obtained from the environment of Sekolah Farmasi, Institut Teknologi Bandung, Indonesia. Both plant tissue cultures and hairy root cultures of $A$. annua were obtained from Plant Tissue Culture Laboratory, Sekolah Farmasi, Institut Teknologi Bandung, Indonesia.
Methods [13]

Preparation of extract

A. annua wild-type (65-days age) plant's root, stem, and leaves were separated (triplicated each). Each part was dried in $40^{\circ} \mathrm{C}$ for $12 \mathrm{hrs}$, followed by grinding. Powder was then macerated with methylene chloride (1:10) using sonicator for 15 minutes. Maceration was done three times to extract all stigmasterol content in plant. Macerate obtained was then filtered and evaporated. The concentrated extract was analyzed for its stigmasterol content using TLC and HPLC. Same protocols were applied to 16-day plant tissue cultures and 35-day hairy root cultures, dried at $60^{\circ} \mathrm{C}$ for $6 \mathrm{hrs}$.

\section{TLC analysis}

About $5 \mu \mathrm{l}$ of sample was used for each analysis. For development, a mixture of ethylacetate/n-hexane $(1: 9, v / v)$ was used. Visualization was done under UV light ( $\lambda 254 \mathrm{~nm}$ ) and $10 \% \mathrm{H}_{2} \mathrm{SO}_{4}$ solution in methanolspray followed by $120^{\circ} \mathrm{C}$ heating for 3 minutes.

\section{Stigmasterol content determination}

For HPLC analysis, the following conditions were applied: $1 \mathrm{ml} / \mathrm{min}$ flow rate, $20 \mu \mathrm{l}$ of sample injected, detection at $\lambda 210 \mathrm{~nm}$, and water/methanol (1:99) as the eluent. Before injection, the extract was dissolved in $3 \mathrm{ml}$ absolute ethanol [14]. Method validity was assessed based on all test parameters to cover the range of samples and concentration involved. Tests were done in triplicates. A standard curve was generated from integrated peak area and concentration of the same standard expressed as \% recovery of the sample. The equations cover the range of concentration used in sample determination, having acceptable correlation coefficient $(r>0.999)$ [15].

\section{Phytosterol types determination}

The preparation of sample solution (197.4 mg of $A$. annua hairy root cultures extract) was done by ultrasonic treatment; anhydrous methylene chloride was used as a solvent. The operational conditions 
for the GC-MS instrument were as follows mobile phase flow rate of $1 \mathrm{ml} / \mathrm{min}$, column temperature of $100^{\circ} \mathrm{C}$ for 2 minutes, risen up to $320^{\circ} \mathrm{C}$ at the rising speed of $10^{\circ} \mathrm{C} / \mathrm{min}$, and kept constant at $320^{\circ} \mathrm{C}$ for 25 minutes. Ionization mode was electron ionization with electron energy of $70 \mathrm{eV}$. The volume of sample loaded was $1 \mu \mathrm{l}$.

\section{RESULTS}

TLC profile showed that the leaves, stem, and root of $A$. annua wild-type plant and plant tissue cultures both contains stigmasterol, indicated by a spot having the same Rf as standard stigmasterol. A. аnnua hairy root cultures show same results (Fig. 1). Linear regression of stigmasterol

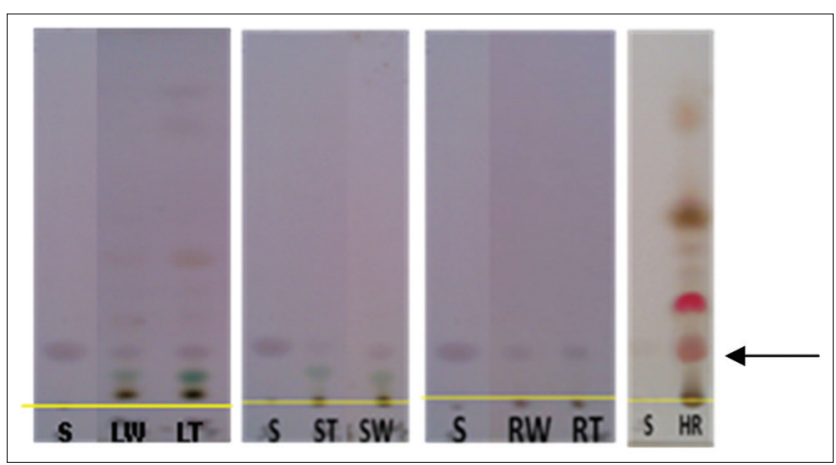

Fig. 1: Thin layer chromatography profile of $A$. annua, $\mathbf{S}=$ Standard stigmasterol, $\mathbf{L W}=$ Plant leaves, $\mathbf{L T}=$ Plant tissue cultures leaves, $\mathrm{ST}=$ Plant stem, $\mathrm{SW}=$ Plant tissue cultures stem, RW = Plant root, $\mathrm{RT}=$ Plant tissue cultures root, $\mathrm{HR}=$ Hairy root cultures content in $A$. апnиa wild-type plant and plant tissue cultures is $\mathrm{Y}=6551.79 \mathrm{x}+2896.12$ with correlation coefficient $\mathrm{r}=0.9999$. Based on that, stigmasterol content in $A$. апnиa wild-type plant found in leaves, stems, and roots were $0.19 \pm 0.1 / 100$ g extract, $0.42 \pm 0.3 / 100$ g extract, and $0.19 \pm 0.0 \mathrm{~g} / 100 \mathrm{~g}$ extract, respectively; although stigmasterol content in A. annua plant tissue cultures was found only in the leaves, that was $1.37 \pm 0.0 \mathrm{~g} / 100 \mathrm{~g}$ extract. While stigmasterol content was not detected in stem and root section of the A. апnиa plant tissue cultures. The linear regression of stigmasterol content in A. аnnua hairy root cultures is $37505.58 \mathrm{x}+663.12$, with correlation coefficient $\mathrm{r}=0.9998$. Linear regression equation proves that stigmasterol content in $A$. апnиa hairy root cultures was $1.57 \pm 0.7 \mathrm{~g} / 100 \mathrm{~g}$ extract. Hence, the highest stigmasterol content in $A$. аnnua was found in $A$. аnnua hairy root cultures in the $5^{\text {th }}$ week with amount of $1.5 \mathrm{~g} / 100 \mathrm{~g}(\mathrm{w} / \mathrm{w})$ extract. These findings are supported by the fact that based on the GC-MS spectrum profile, in the A. апnиa hairy root cultures extract, stigmasterol, $\beta$-sitosterol and campesterol which were found at retention time 25.4, 25.9 , and 25.2 minutes and $\mathrm{m} / \mathrm{z}$ value shows the molecular weight of $412.5,414.5$, and 400.7, respectively. Those phytosterol types were shown in Figs. 2-4, respectively. Based on normalized of the GC-MS area, the three major percentages of phytosterols were stigmasterol $74.6 \%$, $\beta$-sitosterol 13.5\%, and campesterol 11.9\%, respectively.

\section{DISCUSSION}

The highest amount of stigmasterol content in A. annua hairy root cultures extract and the reason might be explained by plant regenerative mechanism. In case that $A$. апnи plant was transformed by $A$. rhyzogenes $r i$, there is a possibility that plant was damaged by bacteria, and bacteria enters into as pathogen. The Squalene synthase (SQS) gene-silenced plants were susceptible to a wide range of pathogens compared to wild-type plants [16]. SQS roles in phytosterol

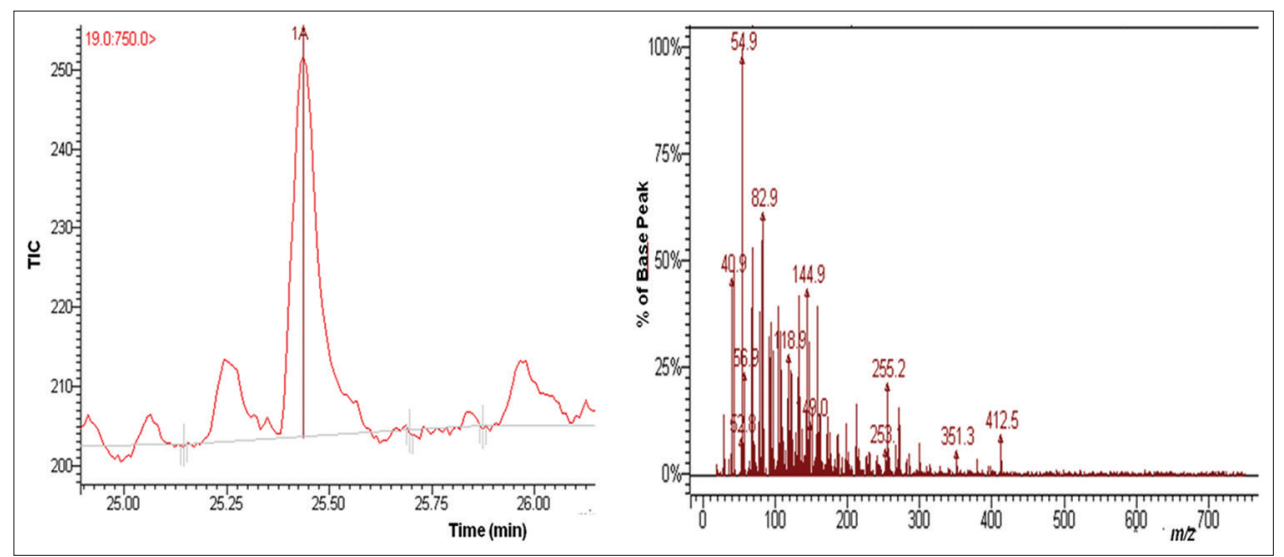

Fig. 2: Gas chromatography-mass spectrometry spectrum profile of stigmasterol

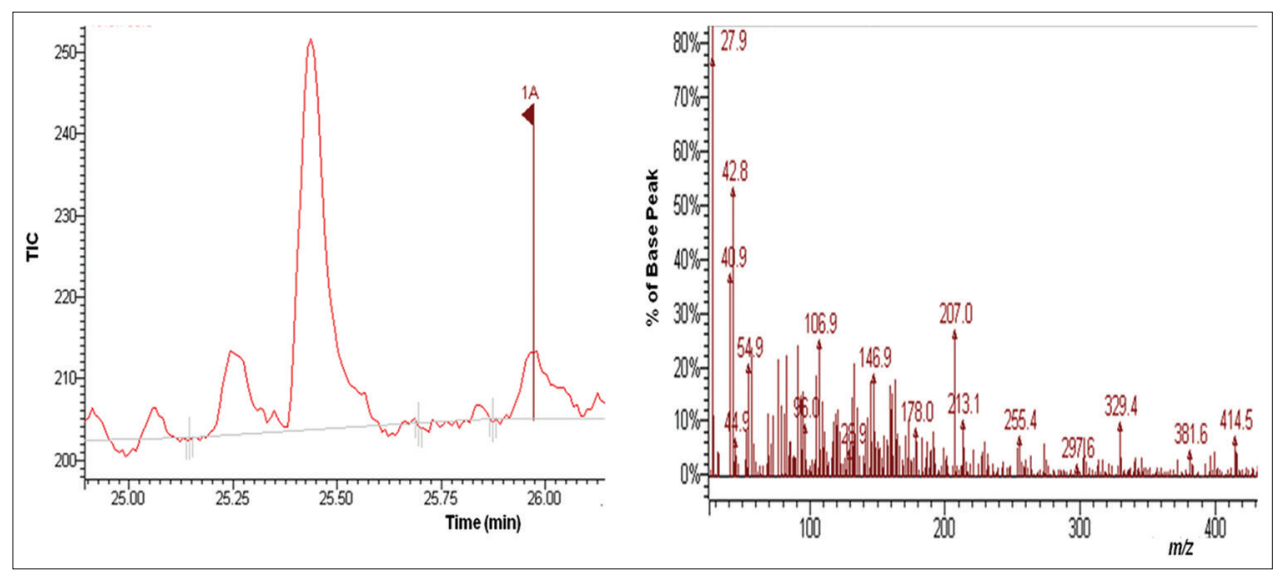

Fig. 3: Gas chromatography-mass spectrometry spectrum profile of ß-sitosterol 


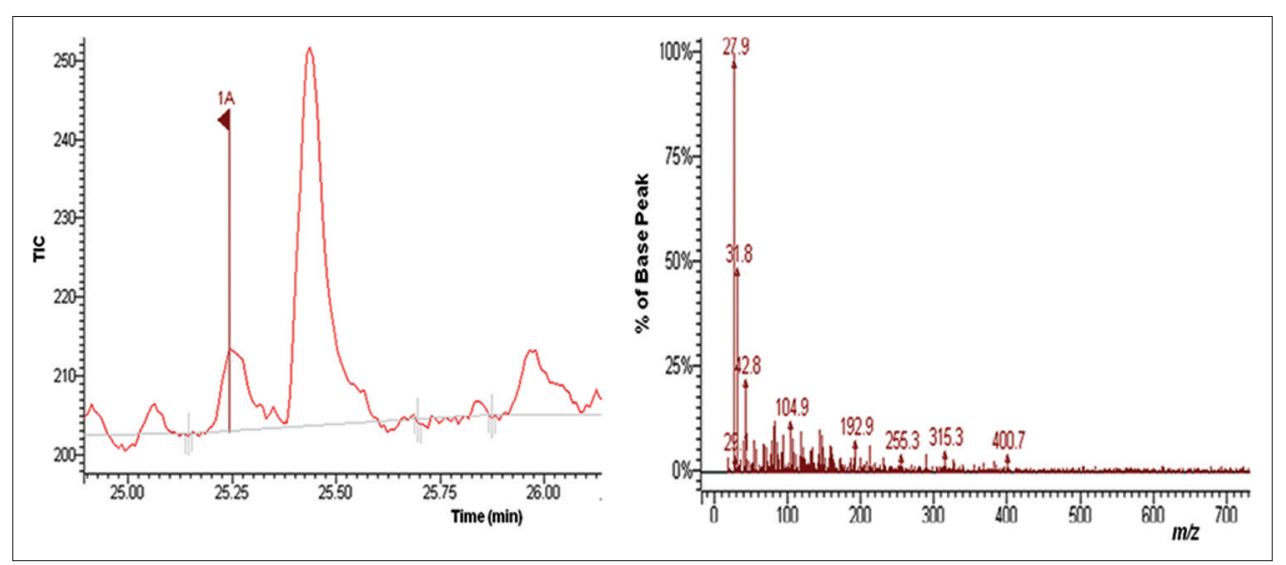

Fig. 4: Gas chromatography-mass spectrometry spectrum profile of campesterol

synthesis [17]. While phytosterols play a key role in plant innate immunity against bacterial. Obtaining stigmasterol from hairy root cultures is beneficial, since it takes little space, allows control of quality and safety, gives faster growth resulting in sooner harvesting time compared to conventional growth and relatively more environmentfriendly since it does not affect the ecosystem.

\section{CONCLUSION}

Hairy root cultures, as one of the plant tissue culture techniques, are one possible method to increase plant metabolite content in a plant. This condition was consistent with the statement that the resulting genetically transformed root cultures which have possibility to produce a high content of secondary metabolites, comparable or even higher compared to intact plants [18]. A. annua hairy root cultures prove to be a potential candidate as an alternative for stigmasterol source. The profile of phytosterol types in A. annua L. hairy root cultures showed different profile compared to common plants, the highest phytosterol type in hairy root cultures is the stigmasterol.

\section{ACKNOWLEDGMENT}

AuthorsthankDr. RoyA.Sparringa M.App.Sc., T.BahdarJohanH.M.Pharm., and Lucky Slamet M.Sc., for their sincere recommendation. Loise Riani Sirait, M.Si., Riswahyuli, M.P., at the imaging facility for help with GC-MS. Mr. Udin Bifadhlilah and Iman Sulaiman S.Si., for helping with stigmasterol quantification. Ardi Rustamsyah M.Si., for help hairy root subculture. This study was supported by National Agency of Drug and Food Control, Republic of Indonesia, No.KP.11.243.08.13.05887 and Institut Teknologi Bandung, Indonesia.

\section{REFERENCES}

1. Brufau G, Canela MA, Rafecas M. Phytosterols: Physiologic and metabolic aspects related to cholesterol-lowering properties. Nutr Res 2008;28(4):217-25.

2. Chen WP, Yu C, Hu PF, Bao JP, Tang JL, Wu LD. Stigmasterol blocks cartilage degradation in rabbit model of osteoarthritis. Acta Biochim Pol 2012;59(4):537-41.

3. Gabay O, Sanchez C, Salvat C, Chevy F, Breton M, Nourissat G, et al. Stigmasterol: A phytosterol with potential anti-osteoarthritic properties. Osteoarthritis Cartilage 2010;18(1):106-16.

4. Katz M, Bartov I, Budowski P, Bondi A. Inhibition of cholesterol deposition in livers of mice fed phytosterols in short-term experiments. J Nutr 1970;100(10):1141-7.
5. Batta AK, Xu G, Honda A, Miyazaki T, Salen G. Stigmasterol reduces plasma cholesterol levels and inhibits hepatic synthesis and intestinal absorption in the rat. Metabolism 2006;55(3):292-9.

6. Vahouny GV, Connor WE, Subramaniam S, Lin DS, Gallo LL. Comparative lymphatic absorption of sitosterol, stigmasterol, and fucosterol and differential inhibition of cholesterol absorption. Am J Clin Nutr 1983;37:805-9.

7. Chandler RF, Hooper SN, Ismail HA. Antihypercholesterolemic studies with sterols: Beta-sitosterol and stigmasterol. J Pharm Sci 1979;68(2):245-7.

8. European Food Safety Authority (EFSA). Scientific opinion on the safety of stigmasterol-rich plant sterols as food additive. EFSA J 2012;10(5):2659.

9. Martins CM, Fonseca FA, Ballus CA, Figueiredo-Neto AM, Meinhart AD, de Godoy HT, et al. Common sources and composition of phytosterols and their estimated intake by the population in the city of São Paulo, Brazil. Nutrition 2013;29(6):865-71.

10. Gharehmatrossian S, Popov Y, Ghorbanli M, Safaeian S. In-vitro culture of Artemisia aucheri boiss on four different tissue culture media for comparative cytotoxic effect sand growth. Asian J Pharm Clin Res 2014;7 Suppl 1:27-31.

11. Xie D, Wang L, Ye H, Li G. Isolation and production of artemisinin and stigmasterol in hairy root cultures of Artemisia annua. Res Note Plant Cell Tissue Organ Cult 2000;63(2):161-6.

12. Chammearc NS, Elfahmi, Suhandono S. Genetic Transformation of Artemisia annua L. Using Agrobacterium rhizogenes strain ATCC15834, A4, and 07-20001. Essay, School of Pharmacy, ITB; 2012. p. 1-43.

13. Bisht R, Chanyal S, Agrawal PK. Antimicrobial and phytochemical analysis of leaf extract of medicinal fruit plants. Asian J Pharm Clin Res 2016;9(4):1-6.

14. Sheng Y, Chen XB. Isolation and identification of an isomer of $\beta$-sitosterol by HPLC and GC-MS. Health 2009;1(3):203-6.

15. Bhuvaneshwari K, Gokulanathan A, Jayanthi M, Govindasamy V, Milella L, Lee S, et al. Can Ocimum basilicum L. and Ocimum tenuiflorum L. in vitro culture be a potential source of secondary metabolites. Food Chem 2016;194:55-60.

16. Wang K, Senthil-Kumar M, Ryu CM, Kang L, Mysore KS. Phytosterols play a key role in plant innate immunity against bacterial pathogens by regulating nutrient efflux into the apoplast. Plant Physiol 2012;158(4):1789-802.

17. Weathers PJ, Elkholy, Wobbe AK. Invited review: Artemisinin: The biosynthetic pathway and its regulation in Artemisia annua, a terpenoidrich species, in vitro vell. Dev Biol Plant 2006;42:309-17.

18. Georgiev MI, Pavlov AI, Bley T. Hairy root type plant in vitro systems as sources of bioactive substances. Appl Microbiol Biotechnol 2007;74(6):1175-85. 